\title{
The effect of a diet education with six iso-caloric meals on the body weight and blood glucose of diabetes type 2 patients
}

\author{
O efeito de educação de dieta com seis iso-calórico refeições no diabetes tipo 2 pacientes de \\ peso corporal e glicose no sangue
}

\author{
Musa SALEHI ${ }^{1}$, Abbas YOUSEFINEJAD ${ }^{2 *}$, Gholamreza PISHDAD ${ }^{3}$
}

\begin{abstract}
The treatment of Diabetes should not only be sought through drug administration; diet is also a part of its treatment. The aim of this study was to determine the effect of a diet with six meals having equal calories on the body weight and blood glucose on diabetes type 2 patients. This research is an Experimental study conducted in 2009 on 181 patients with diabetes. The patients visited the IDSF (Iranian Diabetes Society of Fars) weekly and the patients to be studied were randomly divided into two groups of 85 and 96 patients, respectively. The participants were repeatedly requested to consume their calculated calorie in six equal parts. The average age in the Experimental and Control groups were $51.2 \pm 13.3$ and $53.1 \pm 9.4$, respectively. The mean body weight and fasting blood glucose at the beginning of the study in Experimental and Control groups were $66.3 \pm 9.4$ and $69.1 \pm 11.1 \mathrm{~kg}, 198.9 \pm 35.1$, and $199.8 \pm 39.1 \mathrm{mg} . \mathrm{dL}^{-1}$, respectively. At the end of the study, however, the values were $63.5 \pm 7.5$ and $66.98 \pm 9 \mathrm{~kg}, 139.5 \pm 34.6$ and $164.2 \pm 22.1 \mathrm{mg} . \mathrm{dL}^{-1}$, respectively. Only the mean fasting blood glucose at the end of the study revealed a significant difference $(\mathrm{p}$-value $=0.001$ ). The results show that educating those afflicted with Diabetes Type 2 aiming at changing their diet can greatly help them manage their blood glucose.

Keywords: calorie; diabetes; glucose; meal.
\end{abstract}

\section{Resumo}

O tratamento do diabetes não deve ser buscado apenas através do uso de medicação; a dieta também é uma parte do tratamento. O objetivo deste estudo é determinar o efeito de uma dieta de 6 refeições de igual valor calórico sobre o peso corporal e glicose no sangue de pacientes portadores de diabetes tipo 2. Esta pesquisa foi feita em $2009 \mathrm{com} 181$ pacientes com diabetes. Os pacientes frequentavam o IDSF (Sociedade Iraniana de Diabete de Fars) uma vez por semana e os pacientes a serem estudados foram randomicamente divididos em dois grupos de 85 e 96 pacientes, respectivamente. Aos participantes era solicitado que consumissem em 6 partes iguais suas calorias calculadas. A média de idade do grupo experimental e controle foi 51,2 \pm 13,3 e 53,1 $\pm 9,4$, respectivamente. O peso corporal médio e a glicemia de jejum no início do estudo foram $66,3 \pm 9,4$ e $69,1 \pm 11,1 \mathrm{~kg}, 198,9 \pm 35,1$ e $199,8 \pm 39,1 \mathrm{mg} \cdot \mathrm{dL}^{-1}$, respectivamente. No final do estudo, entretanto, os valores foram 63,5 \pm 7,5 e 66,98 $\pm 9 \mathrm{~kg}, 139,5 \pm 34,6$ e 164,2 $\pm 22,1 \mathrm{mg} . \mathrm{dL}$, respectivamente. Apenas a média da glicemia de jejum no final do estudo revelou uma diferença significativa (P-valor $=0,001$ ). Os resultados mostram que educar pacientes com o diabetes tipo 2 , focando na mudança de suas dietas, pode contribuir imensamente para a administração da glicose sanguínea.

Palavra-chave: caloria; diabetes; glicose; refeição.

\section{Introduction}

Although many studies focus on the effect of a nutrient or micro-nutrient for prevention or treatment of diabetes and its concomitant diseases such as Coronary Heart Disease and hypertension (ANDERSON et al., 2000; APPEL et al., 1997; HU et al., 2000; HUIJBREGTS et al., 1997; KANT et al., 2000; LIU et al., 2000a,b), according to recent studies, it is difficult to believe that only one of the micro-nutrients can manage diabetes. As a matter of fact, other alimentary patterns can be designated for diabetes treatment as well including food plans, increasing the number of meals per day, time span between the meals, etc. They all seem to have a bearing on diabetes prevention or its incidence (AMERICAN..., 2000; ANDERSON et al.,
2000; APPEL et al., 1997; HU et al., 2000; HUIJBREGTS et al., 1997; KANT et al., 2000; LIU et al., 2000a,b). When a person afflicted with diabetes is recommended to control his/her blood glucose by changing food patterns and doing sports, it means self-management education for blood glucose monitoring (MENSING et al., 2000).

Diabetes treatment should not be sought solely through drug prescription. Food diet, food patterns, exercise, food selection, reduction of the amount of food at each meal, etc. are all also known as a part of the treatment process (DIABETES..., 1993b; U. K. PROSPECTIVE..., 1998). It seems that all of the diabetes

${ }^{1}$ Department of Nutrition, School of Health and Nutrition, Shiraz University of Medical Sciences, Shiraz, Iran

2 Department of Nutrition and Biochemistry, School of Public Health, Tehran University of Medical Sciences, Tehran, Iran, e-mail: yousefinejad.abs@gmail.com

3 Endocrinologist, Shiraz University of Medical Sciences, Shiraz, Iran

${ }^{*}$ Corresponding author 
treatment team members, both in groups 1 and 2 have agreed on the fact that any intervention as a treatment of diabetes will respond only under specific circumstances when these treatments cause changes in the patients' lifestyle, physical activities, sports, and food habits (DIABETES..., 1993a, 1995; GLASGOW et al., 1998; SADUR et al., 1999). These lifestyle and behavior patterns modifications include obesity (COLDITZ et al., 1990; 1995), low physical activity (HELMRICH et al., 1991; HU et al., 1999; LYNCH et al., 1996; MANSON et al., 1991), smoking addiction (MANSON et al., 2000; RIMM et al., 1995), low fiber diet with a high Glycemic Index (DIABETES..., 1993b; INSTITUTE..., 2000; U. K. PROSPECTIVE..., 1998) In this study, we refer to obesity as the body mass index higher than 25 (SALMERON et al., 1997). Doing sport is defined as activities done twice a day with the duration of at least 30 minutes including jogging which causes rapid breathing (LIU et al., 2000b; SALMERON et al., 1977). In this study, apart from all the effective instructions on blood glucose control, those with diabetes type 2 should follow a diet with 6 equal parts each with a time span of 3 hours in order to have a better control over the disease. The aim of this study was to determine the effects of a diet education with six meals having equal calories on the body weight and blood glucose control of type 2 diabetic patients.

\section{Materials and method}

The present research was an interventional study on 230 patients carried out in 2009. The patients participated regularly in educational classes held by IDSF (Iranian Diabetes Society of Fars). 181 members volunteered to take part in the study. They were randomly divided into two groups of 85 and 96 members denominated experimental and control groups, respectively. They were introduced to an educational center. The training courses held for both groups were exactly the same, except for the fact that each group was instructed to properly select its food supply according to Harris-Benedict equation in terms of the members' weight, age, height, and sex and have it divided into six equal meal parts. Next, they were instructed to consume each part with a time span of 3 hours. In the control group, they were not required to follow the regulations as they were instructed. Therefore, their food plan, which was similar to most patients with diabetes type 2, included three main meals with two snacks in between. An endocrinologist and a general physician also cooperated as relevant executors in this study. The general physician and laboratory operator were blinded to the group assignment. In the beginning of this study, a test of blood glucose, height, and weight was performed on fasting and their age and sex were recorded. This procedure continued for three months, and at the end of each week, the important points related to the correction of food habits, proper exercise, and a good diet were emphasized to each group. Moreover, the experimental group was requested to observe not only the above mentioned points but also follow the six part meal routine every day. At the end of the month three, both groups were again tested for fasting blood glucose (FBG), and their corresponding results were recorded.

The endocrinologist changed the medication dose of Sulfonylureas (Glyburide) and Metformin if the patients had experienced a severe decrease in blood glucose. In this study, all the efforts were made in order not to interfere with the type and dose of medication received by patients, unless the patients themselves went to the doctor and asked him/her to do so.

The t-test for Two independent sample was performed using the Statistical Package for the Social Sciences (SPSS) software (version 16), and a p-value of less than 0.05 was considered as the significant level.

\section{Results}

The mean \pm standard deviation of age in the experimental and control groups were $51.2 \pm 13.3$ and $53.1 \pm 9.4$, respectively and the body weight mean \pm standard deviation at the beginning of the study in the experimental and control groups were $66.3 \pm 9.4$ and $69.1 \pm 11.1 \mathrm{~kg}$, respectively. At the end of the study, however, the values were $63.5 \pm 7.5$ and $66.98 \pm 9 \mathrm{~kg}$, respectively. The average of blood glucose in the experimental and control groups at the beginning of the study were $198.9 \pm 35.1$ and $199.8 \pm 39.1 \mathrm{mg} \cdot \mathrm{dL}^{-1}$, and at the end of the study they were $139.5 \pm 34.6$ and $164.2 \pm 22.1 \mathrm{mg} . \mathrm{dL}^{-1}$, respectively.

As seen in Table 1, although the average age, body weight at the beginning and end of study, and FBG at the beginning of the study did not show a remarkable difference in the experimental and control groups, FBG at the end of the study revealed a noticeable difference $(\mathrm{p}$-value $=0.001)$.

As shown in Table 2, the amount of variables obtained showed the same results in women except for the weight

Table 1. Participants' mean and standard deviation for age, weight, and FBG at the beginning and end of the study.

\begin{tabular}{|c|c|c|c|c|c|}
\hline \multirow[t]{2}{*}{ Variables } & \multicolumn{2}{|c|}{$\begin{array}{l}\text { Experimental } \\
\quad(\mathrm{n}=85)\end{array}$} & \multicolumn{2}{|c|}{$\begin{array}{l}\text { Control } \\
(\mathrm{n}=96)\end{array}$} & \multirow[t]{2}{*}{$\mathrm{p}$-value } \\
\hline & Mean & St. D & Mean & St. D & \\
\hline Age & 51.2 & 13.3 & 53.1 & 9.4 & 0.46 \\
\hline $\begin{array}{l}\text { Weight at the beginning of } \\
\text { study }(\mathrm{kg})\end{array}$ & 66.3 & 9.4 & 69.1 & 11.1 & 0.24 \\
\hline $\begin{array}{l}\text { Weight at the end of study } \\
(\mathrm{kg})\end{array}$ & 63.5 & 7.5 & 66.98 & 9 & 0.69 \\
\hline $\begin{array}{l}\text { FBG at the beginning of } \\
\text { study }\left(\mathrm{mg}^{-} \mathrm{dL}^{-1}\right)\end{array}$ & 198.9 & 35.1 & 199.8 & 39.1 & 0.91 \\
\hline $\begin{array}{l}\text { FBG at the end of study } \\
\left(\mathrm{mg} \cdot \mathrm{dL}^{-1}\right)\end{array}$ & 139.5 & 34.6 & 164.2 & 22.1 & 0.001 \\
\hline
\end{tabular}

St. D: Standard deviation.

Table 2. Women's mean and standard deviation for age, weight, and FBG at the beginning and end of the study.

\begin{tabular}{|c|c|c|c|c|c|}
\hline \multirow[t]{2}{*}{ Variables } & \multicolumn{2}{|c|}{$\begin{array}{l}\text { Experimental } \\
(\mathrm{n}=45)\end{array}$} & \multicolumn{2}{|c|}{$\begin{array}{l}\text { Control } \\
(\mathrm{n}=53)\end{array}$} & \multirow[t]{2}{*}{$\mathrm{p}$-value } \\
\hline & Mean & St. D & Mean & St. D & \\
\hline Age & 48.9 & 14.2 & 52.6 & 9.8 & 0.26 \\
\hline $\begin{array}{l}\text { Weight at the beginning of } \\
\text { study }(\mathrm{kg})\end{array}$ & 64 & 7.7 & 68.8 & 12.3 & 0.077 \\
\hline $\begin{array}{l}\text { Weight at the end of study } \\
(\mathrm{kg})\end{array}$ & 61.7 & 5.8 & 67.00 & 9.5 & 0.022 \\
\hline 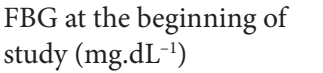 & 200.2 & 28.6 & 200.1 & 40.7 & 0.99 \\
\hline $\begin{array}{l}\text { FBG at the end of study } \\
\left(\mathrm{mg} \cdot \mathrm{dL}^{-1}\right)\end{array}$ & 148.7 & 32.7 & 162.8 & 21.8 & 0.056 \\
\hline
\end{tabular}

St. D: Standard deviation 
factor at the end of the study, which had different values in the experimental and control groups. According to the results shown in Table 3, for men, the findings proved that at the beginning and end of the study there was no significant difference in the average weight, age, and FBG at the beginning of the study for the control and experimental groups. Only for FBG at the end of the study was this difference meaningful ( $p$-value $=0.001$ ). The comparison of the difference in FBG before and after the education period for the control and experimental groups considering the sex factor can be seen in Table 4 . The results showed that the experimental group was more affected than the control group; in women, as expected, this effect was not statistically meaningful.

The repetitive measurement results are shown in graph (Figure 1). According to the results, during the first two months, the FBG decreased greatly ( $p<0.001)$, and in the last month there was no significant difference $(p=0.116)$. The repetitive measurements in graph (Figure 2) show that there was a great difference $(p<0.001)$ in the FBG level for both sexes in all months of the year in comparison to those before the study. However, for men there was a continuous decrease up the last month regardless of the fact that this trend was not noticeable between the first and second months $(p=0.062)$. In addition, there was no difference between the second and last months $(\mathrm{p}=0.104)$. With regard to women, there were different results for different months $(\mathrm{p}=0.021)$, except for the fact that in the last month there was again a rise in blood glucose. Graph (Figure 3) shows the repetitive measurements except for age and Body Mass Index effects. A comparison of a general case and the results obtained showed that there was only a noticeable

Table 3. Men's mean and standard deviation for age, weight, and FBG at the beginning and end of the study.

\begin{tabular}{|c|c|c|c|c|c|}
\hline \multirow[t]{2}{*}{ Variables } & \multicolumn{2}{|c|}{$\begin{array}{l}\text { Experimental } \\
\quad(\mathrm{n}=40)\end{array}$} & \multicolumn{2}{|c|}{$\begin{array}{l}\text { Control } \\
(\mathrm{n}=43)\end{array}$} & \multirow[t]{2}{*}{ p-value } \\
\hline & Mean & St. D & Mean & St. D & \\
\hline Age & 57.3 & 7.9 & 54.4 & 8.2 & 0.43 \\
\hline $\begin{array}{l}\text { Weight at the beginning } \\
\text { of study ( } \mathrm{kg} \text { ) }\end{array}$ & 72.7 & 10.8 & 69.5 & 7.2 & 0.43 \\
\hline $\begin{array}{l}\text { Weight at the end of } \\
\text { study }(\mathrm{kg})\end{array}$ & 68.5 & 9.5 & 66.9 & 5.2 & 0.64 \\
\hline $\begin{array}{l}\text { FBG at the beginning of } \\
\text { study }\left(\mathrm{mg}^{\left.-\mathrm{dL}^{-1}\right)}\right.\end{array}$ & 195.3 & 50.1 & 199.1 & 36.2 & 0.84 \\
\hline $\begin{array}{l}\text { FBG at the end of study } \\
\left(\mathrm{mg} \cdot \mathrm{dL}^{-1}\right)\end{array}$ & 114.5 & 27.5 & 167.9 & 23.6 & 0.001 \\
\hline
\end{tabular}

Table 4. FBG between control and experimental groups based on gender.

\begin{tabular}{|c|c|c|c|c|c|c|}
\hline \multirow[t]{2}{*}{ Gender } & \multirow[t]{2}{*}{$\begin{array}{c}\text { Fasting blood } \\
\text { glucose }\left(\mathrm{mg} \cdot \mathrm{dL}^{-1}\right)\end{array}$} & \multicolumn{2}{|c|}{ Control group } & \multicolumn{2}{|c|}{$\begin{array}{c}\text { Experimental } \\
\text { group }\end{array}$} & \multirow[t]{2}{*}{$\mathrm{p}$-value } \\
\hline & & Mean & St. D & Mean & St. D & \\
\hline \multirow[t]{3}{*}{ Woman } & Before & 200.1 & 40.72 & 200.23 & 28.84 & 0.99 \\
\hline & After & 169.79 & 21.86 & 148.67 & 32.70 & 0.06 \\
\hline & Difference & 37.31 & 36.95 & 51.56 & 47.52 & 0.21 \\
\hline \multirow[t]{3}{*}{ Man } & Before & 199.09 & 36.18 & 195.27 & 50.06 & 0.84 \\
\hline & After & 167.91 & 23.62 & 114.55 & 27.52 & 0.001 \\
\hline & Difference & 31.18 & 29.62 & 80.73 & 50.58 & 0.01 \\
\hline
\end{tabular}

St. D: Standard deviation

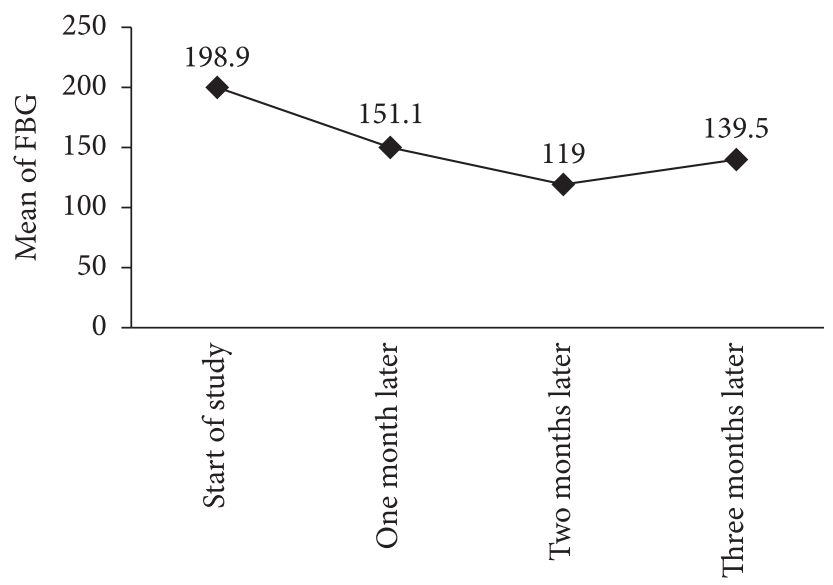

Figure 1. Time graph for FBG fluctuations in the experimental group at the beginning and end of the study.

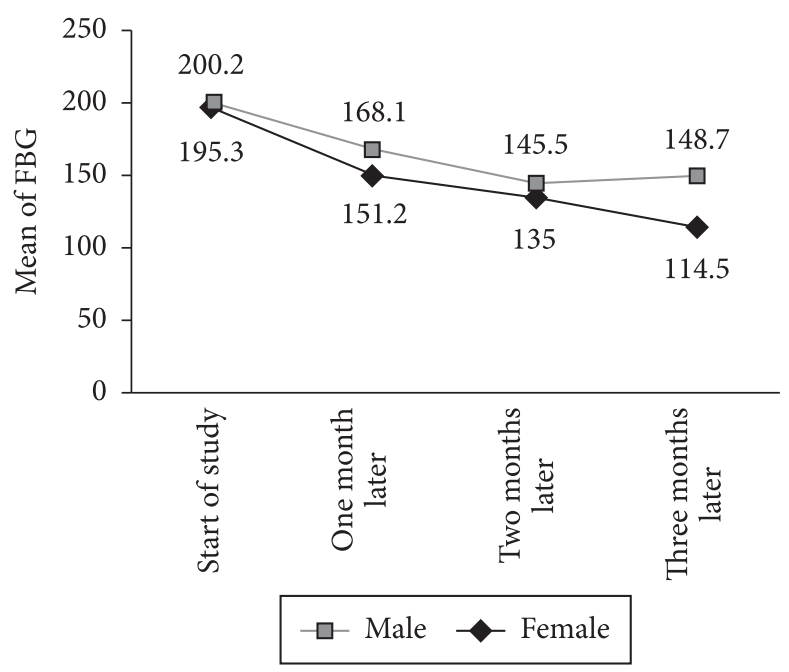

Figure 2. Time graph for FBG fluctuations in the experimental group with regard to sex criteria at the beginning and end of the study.

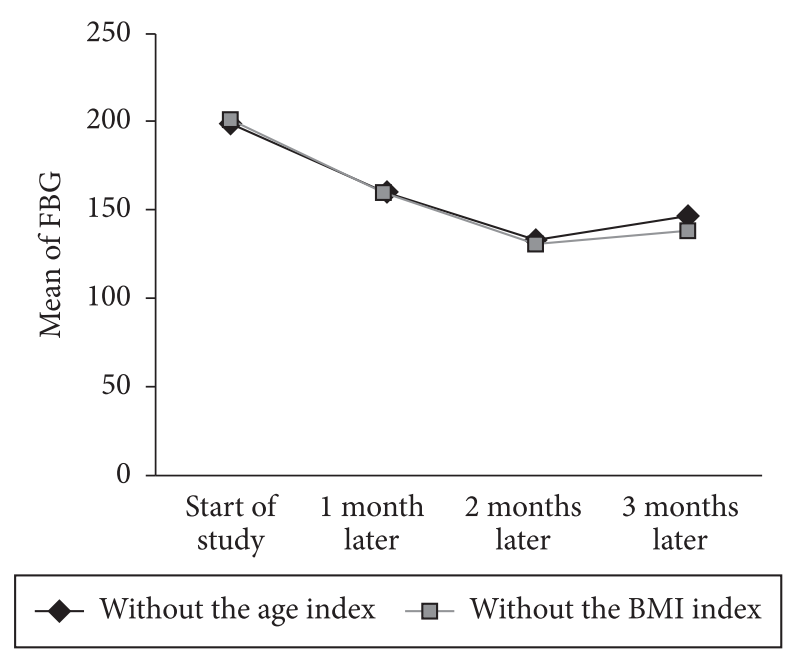

Figure 3. Time graph for FBG changes in the experimental group with the exclusion of age and Body Mass Index at the beginning and end of the study. 
difference in the last month measurements, but with the exclusion of age and Body Mass Index, these differences were significant for all months of the year $(\mathrm{p}=0.047)$.

\section{Discussion and conclusion}

Table 1 shows that for both groups there was no difference between age and weight at the beginning and end of the study and also FBG at the beginning of the study, but there was a reduction of $25 \mathrm{mg} \cdot \mathrm{dL}^{-1}$ in the FBG at the end of the study, which was one of the main goals of this research. It can be inferred that a diet with 6 meal parts and a time span of 3 hours between each meal greatly contributes to the decrease of blood glucose. According to Table 2, the above factors did not show any difference at the end, expect for the weight factor, as expected, and according to Table 3, only the FBG showed a remarkable difference between the experimental and control groups. It seems that the diet recommended in this study has affected women's weight more than men's. The meaningful difference for FBG and body weight in the control and experimental groups proved that educating patients with type 2 diabetes in order to motivate them to change their lifestyle can help them greatly manage their blood glucose (Table 1).The effects of education on blood glucose control have also been proven in other studies (AMERICAN...,2001; 2002; DIABETES..., 1993 a,b; 1995; GLASGOW et al., 1998; INSTITUTE..., 2000; MENSING et al., 2000; SADUR et al., 1999; U. K. PROSPECTIVE..., 1998). Table 4 not only shows the effect of education but also that the diet plan is more effective in blood glucose control which was the ultimate goal of this study as well. However, this diet plan did not affect the patient's body weight as it was supposed to because it seems that the assessment of the body weight changes with diet plan needs more time (Table 1). Perhaps, while showing some side effects of blood glucose incidence, the continuous weekly sessions of education motivated the participants and caused both groups to change their lifestyle. Weight control in the present study was considered as an important part for both the control and experimental groups. The weight index for both groups at the end of the study period had meaningfully changed, and this proved the important effect of education. Another similar study on weight control in Boston also corroborated the results obtained in this study (COLDITZ et al., 1990; 1995).

What was conducted in this experiment for the first time was the division of diet into six equal parts based on the calorie consumption for patients with type 2 diabetes. The researchers believe that the metabolic load of each cell in the human being, when divided and distributed, can be handled better leading to a more efficient metabolism. Laboratory studies proved that the amount of food obtained by cells can regulate the metabolism process (COHN; JOSEPH, 1960). Instead of imposing a great amount of enzyme activities during digestion, it would be better to reduce the amount of food received by cell, i.e. reducing the calorie received per meal without cutting short any calorie amount from the whole food during a day thereby reducing the metabolic pressure on cells (COHN; JOSEPH, 1960). In another study, the effect of increasing the number of meals and reducing the amount on type 2 diabetes in order to establish a model for reducing the absorption of nutrients per time unit was studied.
According to the results, in a single day, the total amount of food was distributed into 13 parts with low amount and on the next day it was distributed into 3 meals with high amounts (Equal to whole daily calorie). In this project, using food plan with a high number of meals, reduced the average amount of the patients' blood glucose ( $\mathrm{p}=0.006)$ (HELMRICH et al., 1991). Many professional athletes and nutritionists suggest that the amount of food taken each day should be divided into six equal meals in order to obtain the optimum metabolic efficiency. It has previously been proved that three meals per day instead of one meal with a great amount of food and two small meals per day can meaningfully decrease the average serum cholesterol level (PAVEL et al., 1970). About half a century ago, it was shown that for those patients with diabetes type 1 , increasing the number of meals per day and decreasing the amount of food per meal can both decrease the necessary insulin level for injection and help the patient to have a better control over blood glucose (JENKINS et al., 1992). Decreasing the amount of food and increasing the number of meals per day is of outmost importance for those with type 2 diabetes because it controls the blood glucose and insulin level for injection (JENKINS et al., 1992). Those meals should be consumed in equal time spans and calorie amount; no other food is supposed to be eaten between the meals (JENKINS et al., 1992). In this study, the participants were weekly and repeatedly requested to equally consume the calculated calorie amounts within 6 meals each 3 hours. This food plan was so effective that in the early days of the study, the patients were referred to an endocrinologist, who participated in this study, and requested a reduction in their medication dose.

\section{References}

AMERICAN DIABETES ASSOCIATION. American Diabetes Association Provider Recognition Program. Disponível em: $<$ http:/www.diabetes.org/recognition/Provider $>$. Acesso em: jan. 2001.

AMERICAN DIABETES ASSOCIATION. American Diabetes Association: standards of medical care for patients with diabetes mellitus (Position Statement). Diabetes Care, v. 25, p. S33-S49, 2002. Suplemento 1.

ANDERSON, J. W. et al. Whole grain food and heart disease risk. Journal of the American College of Nutrition, v. 19, p. 291S-299S, 2000.

APPEL, L. J. et al. A clinical trial of the effects of dietary patterns on blood pressure. New England Journal of Medicine, v. 336, p. 1117-1124, 1997. PMid:9099655. http://dx.doi.org/10.1056/ NEJM199704173361601

COHN, C.; JOSEPH, D. Effects on metabolism produced by the rate of ingestion of the diet. American Journal of Clinical Nutrition, v. 8, p. 682-690, 1960.

COLDITZ, G. A. et al. Weight gain as a risk factor for clinical diabetes mellitus in women. Annals of Internal Medicine, v. 122, p. 481-486, 1995.

COLDITZ, G. A. et al. Weight as a risk factor for clinical diabetes in women. American Journal of Epidemiology, v. 132, p. 501-513, 1990.

DIABETES CONTROL AND COMPLICATIONS TRIAL RESEARCH GROUP. Expanded role of the dietitian in the diabetes control and complications trial: implications for practice. Journal of the 
American Dietetic Association, v. 93, p. 758-767, 1993a. http:// dx.doi.org/10.1016/0002-8223(93)91748-F

DIABETES CONTROL AND COMPLICATIONS TRIAL RESEARCH GROUP. The effect of intensive treatment of diabetes on the development and progression of long-term complications in insulindependent diabetes mellitus. New England Journal of Medicine, v. 329, p. 977-986, 1993b. PMid:8366922. http://dx.doi.org/10.1056/ NEJM199309303291401

DIABETES CONTROL AND COMPLICATIONS TRIAL RESEARCH GROUP. Implementation protocols in the Diabetes Control and Complications Trial. Diabetes Care, v. 18, p. 361-376, 1995. PMid:7555480. http://dx.doi.org/10.2337/diacare.18.3.361

GLASGOW, R. E. et al. Improving self-care among older patients with type II diabetes: the "Sixty Something..." study. Patient Education and Counseling, v. 19, p. 61-74, 1998. http://dx.doi. org/10.1016/0738-3991(92)90102-O

HELMRICH, S. P. et al. Physical activity and reduced occurrence of non-insulin-dependent diabetes mellitus. New England Journal of Medicine, v. 325, p. 147-152, 1991. PMid:2052059. http://dx.doi. org/10.1056/NEJM199107183250302

HU, F. B. et al. Walking compared with vigorous physical activity and risk of type 2 diabetes in women: a prospective study. Journal of the American Medical Association, v. 282, p. 1433-1439, 1999. http://dx.doi.org/10.1001/jama.282.15.1433

HU, F. B. et al. Prospective study of major dietary patterns and risk of coronary heart disease in men. American Journal of Clinical Nutrition, v. 72, p. 912-921, 2000. PMid:11010931.

HUIJBREGTS, P. et al. Dietary patterns and 20 year mortality in elderly men in Finland, Italy, and the netherlands: longitudinal cohort study. British Medical Journal, v. 315, p. 13-17, 1997. http://dx.doi. org/10.1136/bmj.315.7099.13

INSTITUTE OF MEDICINE. The role of nutrition in maintaining health in the nation's elderly: evaluating coverage of nutrition services for the medicare population. Washington: National Academy Press, 2000.

JENKINS, D. J. et al. Metabolic advantages of spreading the nutrient load: effects of increased meal frequency in non-insulin-dependent diabet. American Journal of Clinical Nutrition, v. 155, p. 461-467, 1992.

KANT, A. K. et al. A prospective study of diet quality and mortality in women. Journal of the American Medical Association, v. 283, p. 2109-2115, 2000. http://dx.doi.org/10.1001/jama.283.16.2109

LIU, S. et al. Fruit and vegetable intake and risk of cardiovascular disease: the women's health study. American Journal of Clinical Nutrition, v. 72, p. 922-928, 2000a. PMid:11010932.

LIU, S. et al. A prospective study of whole-grain intake and risk of type 2 diabetes mellitus in U.S. women. American Journal of Public Health, v. 90, p. 1409-1415, 2000b. PMid:10983198. PMCid:1447620. http://dx.doi.org/10.2105/AJPH.90.9.1409
LYNCH, J. et al. Moderately intense physical activities and high levels of cardio respiratory fitness reduce risk of non-insulin-dependent diabetes mellitus in middle-aged men. Archives of Internal Medicine, v. 156, p. 1307-1314, 1996. PMid:8651839. http://dx.doi. org/10.1001/archinte.1996.00440110073010

MANSON, J. E. et al. Physical activity and incidence of noninsulin-dependent diabetes mellitus in women. Lancet, v. 338, p. 774-778, 1991.

MANSON, J. E. et al. A prospective study of cigarette smoking and the incidence of diabetes mellitus among US male physicians. American Journal of Medicine, v. 109, p. 538-542, 2000. http://dx. doi.org/10.1016/S0002-9343(00)00568-4

MENSING, C. et al. National standards for diabetes self-management education (Standards and Review Criteria). Diabetes Care, v. 23, p. 682-689, 2000. http://dx.doi.org/10.1016/0140-6736(91)90664-B

PHYSICAL. Activity and cardiovascular health. NIH consensus development panel on physical activity and cardiovascular health. Journal of the American Medical Association, v. 276, p. 241-246, 1996. http://dx.doi.org/10.1001/ jama.1996.03540030075036

PATE, R. R. et al. Physical activity and public health: a recommendation from the Centers for Disease Control and Prevention and the American College of Sports Medicine. Journal of the American Medical Association, v. 273, p. 402-407, 1995. http://dx.doi. org/10.1001/jama.1995.03520290054029

PAVEL, F.; JAY, T. Meal frequency: a possible factor in human pathology. American Journal of Clinical Nutrition, v. 23, p. 1059-1068, 1970.

RIMM, E. B. et al. Prospective study of cigarette smoking, alcohol use, and the risk of diabetes in men. British Medical Journal, v. 310, p. 555-559, 1995. PMid:7888928. PMCid:2548937. http://dx.doi. org/10.1136/bmj.310.6979.555

SADUR, C. N. et al. Diabetes management in a health maintenance organization. Diabetes Care, v. 22, p. 2011-2017, 1999. PMid:10587835. http://dx.doi.org/10.2337/diacare.22.12.2011

SALMERON, J. et al. Dietary fiber, glycemic load, and risk of NIDDM in men. Diabetes Care, v. 20, p. 545-550, 1977. PMid:9096978. http://dx.doi.org/10.2337/diacare.20.4.545

SALMERON, J. et al. Dietary fiber, glycemic load, and risk of noninsulin-dependent diabetes mellitus in women. Journal of the American Medical Association, v. 277, p. 472-477, 1997. http:// dx.doi.org/10.1001/jama.1997.03540300040031

U. K. PROSPECTIVE DIABETES STUDY GROUP - UKPDS. Intensive blood-glucose control with sulphonylureas or insulin compared with conventional treatment and risk of complications in patients with type 2 diabetes (UKPDS 33). Lancet, v. 352, p. 837-853, 1998. http://dx.doi.org/10.1016/S0140-6736(98)07019-6 